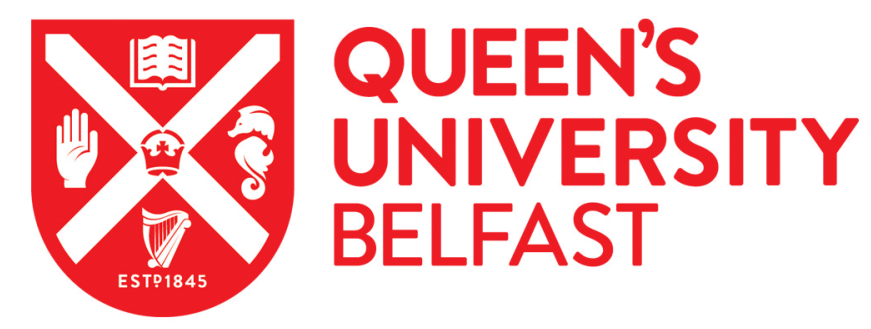

\title{
Redressing Forced Sterilisation: The Role of the Medical Profession
}

Gilmore, S., \& Moffett, L. (2020). Redressing Forced Sterilisation: The Role of the Medical Profession. British Journal of Obstetrics and Gynaecology. https://doi.org/10.1111/1471-0528.16204

Published in:

British Journal of Obstetrics and Gynaecology

Document Version:

Peer reviewed version

Queen's University Belfast - Research Portal:

Link to publication record in Queen's University Belfast Research Portal

Publisher rights

Copyright 2020 Wiley. This work is made available online in accordance with the publisher's policies. Please refer to any applicable terms of use of the publisher.

\section{General rights}

Copyright for the publications made accessible via the Queen's University Belfast Research Portal is retained by the author(s) and / or other copyright owners and it is a condition of accessing these publications that users recognise and abide by the legal requirements associated with these rights.

Take down policy

The Research Portal is Queen's institutional repository that provides access to Queen's research output. Every effort has been made to ensure that content in the Research Portal does not infringe any person's rights, or applicable UK laws. If you discover content in the Research Portal that you believe breaches copyright or violates any law, please contact openaccess@qub.ac.uk. 
2 Full Title: Redressing Forced Sterilisation: The Role of the Medical Profession

3 Authors: Sunneva Gilmore and Luke Moffett

4

Affiliations: School of Law, Queen’s University Belfast (same for both authors)

Contact details of corresponding author: email sgilmore08@qub.ac.uk; address 70 University Road, Belfast, Northern Ireland, BT7 1NN. +442890973459

Running Title: Redressing Forced Sterilisation 
16 Forced sterilisation has been used by many states to control or diminish minority groups.

Examples of forced sterilisation include the Nazis against Jewish, Roma and Sinti peoples and the Imperial Japanese Army in Korea during the Second World War, its historic use against Native Americans in the United States and more recent practice in Peru and the First Nations people in Canada. While it is prohibited under international criminal law, forced sterilisation often involves medical practitioners with little reflection on the context and drivers of such violations within the profession. This article sets out the historic and contemporary struggles for accountability and redress for forced sterilisation, focusing on the role of medical practitioners in such violations. Drawing from interviews conducted in Peru in May 2019, the article also suggests new ways of establishing reparations and offers a critical reflection of ethics for medical practitioners and their role in redress.

\section{Forced Sterilisation}

Sterilisation is considered a permanent surgical form of contraception, either through occlusion or interruption of the fallopian tubes in females or more effectively through vasectomy in males. ${ }^{1}$ Forced sterilisation occurs when informed valid consent is not obtained for the procedure, either through coercion or omission of opportunity to consent. ${ }^{2}$ A number of medical bodies, including FIGO, have issued guidance on properly obtaining consent and ethical issues surrounding sterilisation. ${ }^{3}$ Forced sterilisation is an assault on sexual and reproductive health (SRH); yet, there are limited examples of accountability and redress.

\section{Accountability and Redress for Forced Sterilisation}

During authoritarian regimes and conflict, violence is not only directed at those living, but also at future generations through forced sterilisation that can amount to genocide. However, there have been very few successful instances of justice and limited forms of reparations for victims. Accountability is about ensuring that those responsible for violations are made to answer for their wrongdoing before an individual or institution, including an enforcement 
process for imposing sanctions on those who violate their duties. ${ }^{4}$ Redress has the more victim-oriented perspective of providing a means to seek a remedy for the harm caused. The WHO's statement on forced sterilisation recognises that accountability is 'central to preventing human rights violations' and, for victims, an 'avenue to air their grievances and seek redress'. ${ }^{4}$

After the Second World War, 23 Nazi doctors and public health staff were prosecuted in the 'Medicine case' or 'Doctors' Trial' for murder and torture as war crimes and crimes against humanity. Eight of the individuals were charged with forced sterilisation, including human experimentations with X-rays, surgery and medication, of thousands of Jewish people and other persecuted groups in Auschwitz and Ravensbruck concentration camps. ${ }^{5}$ Three were convicted and executed--mainly those who were involved in developing the policy and oversight of the use of forced sterilisation--but not the doctors, such as Adolf Pokorny, who was acquitted despite writing a letter to Himmler recommending sterilisation. ${ }^{5}$ After the Doctors' Trial in Nuremberg the judges formulated the Nuremberg Code for experiments on human subjects that places voluntary consent as its first principle. Today forced sterilisation is considered a crime against humanity and a war crime under the International Criminal Court (ICC). ${ }^{5}$

As a result of victim and civil society advocacy, Peru is investigating forced sterilisation as a crime against humanity. Forced sterilisation was introduced in Peru in the 1990s by the Fujimori regime through a public health campaign of 'voluntary surgical contraception'. It was intended to reduce the national birth rate using measures such as sterilisation quotas, incentives and penalties, thereby coercing some professionals. ${ }^{6}$ Approximately 300,000 persons, mainly women but also 21,000 men, were forcibly sterilised. ${ }^{7}$ Rural indigenous Quechua-speaking persons were disproportionately targeted, exploiting intersecting vulnerabilities of race and ethno-lingual identity, low socio-economic status, gender (predominately women), and post-partum accessibility to healthcare facilities. Such coercion 
71 included deceiving persons that they would be breaching domestic child policy laws if they

72 had more children and forcing illiterate patients to sign consent forms without an interpreter.

74 Forced sterilisation has been used in a number of non-authoritarian, settled democracies such as in Bangladesh, Sweden, and Switzerland. This reflects the role of discrimination or racism in such procedures, as found by two healthcare professionals' external review of tubal ligation of aboriginal women in the Saskatoon Health Region in Canada. ${ }^{8}$ This discrimination can affect not only the consent process, but also the quality of intra-operative and post-operative care and accuracy of medical records. As a result of unclear documentation in Peru some victims have also been asked to verify their sterilisation through medical evaluations, such as hysterosalpingography. However, some victims described returning to health centres and undergoing invasive gynaecological investigations as traumatic and 'emotionally damaging.'9 The role of the medical profession in carrying out such violations creates challenges for victims seeking remedies and looking for in healthcare providers in whom they can trust.

\section{Appropriate reparations}

Reparations are measures to remedy as far as possible the harm caused. In human rights law, remedying violations like forced sterilisation requires the use of a complementary range of reparations, including restitution, compensation, rehabilitation, measures of satisfaction and guarantees of non-repetition. ${ }^{9}$ These components remedy individuals' harm, like compensation, and more collective ones such as a memorial for the harm to a victim group. Those responsible for making reparations can include individuals, corporations and states. Reparations can contribute to accountability by obliging responsible actors to make amends for their wrongdoing.

In recent years Virginia and North Carolina have introduced compensation for victims of forced sterilisation. ${ }^{10}$ Similarly, Canada has been called by the Inter-American Commission to introduce reparations for First Nation victims. Many victims of forced sterilisation may face 
social and practical barriers in coming forward to claim reparations. They may be silenced through social stigma and shame of lost reproductive capacity or concerned over confidentiality. In Japan, reparation for forced sterilisation was only legislated in 2019 after victims started to bring litigation through the courts; however some victims were prevented by time-bars from bringing claims. Delays may limit options for reparation, such as sterilisation reversal, if appropriate, or urgent socio-economic support and shelter for victims and their children, if ostracised by their family. Thus, non-public disclosure of their identities as well as the option to apply for reparation through civil society organisations can allow access for those who continue to face stigma.

The role of the medical profession in forced sterilisation may create barriers for victims coming forward, in particular when they are required to be medically assessed in order to make a claim for reparations. In Peru some victims expressed concerns that healthcare professionals may be reluctant to engage in these issues when it puts their profession into disrepute and generates a review of current cultures of medical practice for past violations. ${ }^{10}$ For instance, victims of forced sterilisation in the German reparation programme had to demonstrate that their sterilisation was due to racial reasons, not medical ones, and former Nazi doctors often assessed them, tending to reject or reduce their compensation (p.158-164). ${ }^{11}$ Pross found that doctors' role and power as healers obscured their 'social function' as a state actor implementing policy that disrupted that patient-doctor relationship and created 'mutual distrust'(p.177). ${ }^{11}$

Despite the Peruvian Ministry of Health’s apology in 2002 for forced sterilisation, it had little effect on victims and negligible change on the doctors' perception of the policy as legitimate and not a crime against humanity. Similar apologies in Romania by some institutions and a national day commemorating Roma victims have been criticised for not situating forced sterilisation abuses within a historical narrative of responsible actors. Beyond accountability, guaranteeing non-repetition requires public and professional engagement such as school 
textbooks to inform the next generation and medical curricula that includes medical ethics and details of human rights violations committed in healthcare.

The medical profession, in particular the speciality of obstetrics and gynaecology, can take a positive role in shaping appropriate reparation for SRH violations. To illustrate, reparation with free traumatic fistula repair surgery can provide rehabilitation and restoration by means of re-establishing continence. ${ }^{12}$ Reversal of forced sterilisations under the reparation principle restitutio in integrum (restoration to original position) has been a low priority. This is perhaps owing to the often significant time-lapse between the violation and the years or decades it takes for reparations to be implemented, meaning that many females can no longer be fertile. However, victims and reparation designers may also be unaware of medical options such as sterilisation reversal or in vitro fertilisation. Possible reasons for this lack of awareness include limited input from medical experts, requirement for procedures that are not considered routine or widely available, the need for individualised assessment to determine suitability, and the potential cost implications.

Raising awareness of forced sterilisation is also required. There needs to be increased public consciousness that forced sterilisation is a violation. Victims may need to understand that what happened to them was a crime and a breach of medical ethics, and need educating about the right to reparation Societal awareness raising can increase social mobilisation and exert pressure on states to investigate allegations and issue reparation, as in the case with Peru. The Peruvian creation of the Registry of Victims of Forced Sterilizations (REVIESFO) in 2015 has assisted in investigations of claims, but unfortunately there has been no associated reparation programme or educational and institutional reforms to prevent such violations from happening again. Different accountability processes are needed to remedy the wrongdoing of individual and collective actors.

\section{Conclusion}


Medical professionals have played a role in causing violations in the past, but can remedy the psychological or physical harm by providing appropriate care for those who have been harmed. Forced sterilisation in Nazi Germany and Fujimori’s Peru were legal at the time, and in other settled democracies have been part of public policy. Medical practitioners involved in the development of public health policies should resist public pressure to support any form of forced sterilisation. In many countries the marginalisation of victimised groups targeted for forced sterilisation means they often face discrimination, inhibiting their ability to gain public support to seek redress for their suffering. This must not be compounded by the biases and even discrimination that medical professionals may personally hold. In international criminal law medical professionals may be individually criminally responsible for their role in forced sterilisation, despite what the domestic law states. International criminal law does not recognise collective criminal responsibility. However, to address its own past role in such violations there may be moral grounds for responsible medical professionals to make reparations such as apologies, institutional reforms and education to prevent repetition. The medical profession should not only strongly articulate concerns over possible inappropriate medical interventions such as forced sterilisation, but should also advocate for more timely and appropriate reparations.

\section{Disclosure of interests: None}

Contribution to authorship: SG conceived the idea for the paper, planned key content, provided an analysis of the medical profession to reparations and contributed towards the writing up. LM contributed towards the planning and writing up particularly regarding cases in international law and international criminal law aspects.

Details of ethics approval: This research was ethically approved by the ethics committee in the School of Law at Queen's University Belfast in May 2017 and complies with the 2015 ESRC framework for research ethics.

\footnotetext{
Funding: This research was carried out as part of the Arts and Humanities Research Council
} 
${ }^{1}$ Clinical Effectiveness Unit - Faculty of Sexual and Reproductive Healthcare To The Royal College of Obstetricians and Gynaecologists. Clinical Guidance. Male and Female Sterilisation, 01/FSRH/Sterilisation/2014. September 2014. Available from https://www.fsrh.org/standards-andguidance/documents/cec-ceu-guidance-sterilisation-cpd-sep-2014/ [Cited 15 ${ }^{\text {th }}$ November 2019]

${ }^{2}$ Open Society Foundations. Against Her Will. Forced and Coerced Sterilization Worldwide. Stop Torture in Healthcare; October 2011. See Lydia Guterman, The Global Problem of Forced Sterilization, Open Society Foundation Voices, 3 October 2011, available at https://www.opensocietyfoundations.org/voices/global-problem-forced-sterilization

${ }^{3}$ Dickens, B. Female contraceptive sterilization: FIGO Committee for the Ethical Aspects of Human Reproduction and Women's Health. International Federation of Gynecology and Obstetrics 2011 115(1): 88-89. Female Sterilisation. Royal College of Obstetricians and Gynaecologists. Consent Advice No. 3; February 2016.

${ }^{4}$ See Louise Mallinder and Kieran McEvoy, Rethinking amnesties: atrocity, accountability and impunity in post-conflict societies, Contemporary Social Science: Journal of the Academy of Social Sciences, 6(1)(2011), 107-128, p109-111. WHO, Eliminating forced, coercive and otherwise involuntary sterilization, May 2014, p12.

${ }^{5}$ Trials of War Criminals before the Nuernberg Military Tribunals, Vol. I and II, The Medical Case, October 1946 - April 1949. Available from http://www.loc.gov/rr/frd/Military_Law/pdf/NT_warcriminals Vol-I.pdf [cited 27 $7^{\text {th }}$ October 2019]. It is criminalised under the ICC Rome Statute Article 7(1)(g) and Articles 8(2)(b)(xxii) and Article 8(2) (e)(vi), Rome Statute; ICC Elements of Crimes (2011); and Article 2(1)(g), Prevention and punishment of crimes against humanity, International Law Commission A/CN.4/L.935, 15 May 2019.

${ }^{6}$ Study for the Defense of Women's Rights (DEMUS). Report to the Senate of Canada Standing Committee on Human Rights so that Victims of Forced Sterilization Can Seek the Truth, Justice and Comprehensive Reparation, Taking into Account the Experience in Peru, 7 June 2019.

${ }^{7}$ Brown, M., Tucker, K. Unconsented Sterilisation, Participatory Story-Telling, and Digital CounterMemory in Peru, Antipode 2017; 49(5): 1186-1203. El estado debe garantizar justicia y reparaciones para miles de victimas de esterilizaciones forzadas. Amnesty International. 21 October 2015. Available from http://www.amnistia.org.pe/peru-debegarantizar-justicia-reparaciones-para-miles-de-mujeresvictimas-de-esterilizacionesforzadas/ [Cited 18 ${ }^{\text {th }}$ November 2019]. See also the Quipu Project. Available from https://interactive.quipu-project.com/\#/en/quipu/intro [accessed 21 January 2020]

${ }^{8}$ Boyer, Y. Bartlett, J. External Review: Tubal Ligation in the Saskatoon Health Region: The Lived Experience of Aboriginal Women; July 22, 2017.

9 Moffett, L., Transitional Justice and Reparations: Remedying the Past?, in C. Lawther, L. Moffett and D. Jacobs, Research Handbook on Transitional Justice, Elgar; 2017, 377-400.

${ }^{10}$ Focus group with forced sterilisation victims, Lima, May 2019. See similarly Stern, A M., Novak, N L., Lira, N., O’Connor, K., Harlow, S., Kardia, S. California’s Sterilization Survivors: An Estimate and Call for Redress, American Journal of Public Health. 2017; 107(1): 50-54.

${ }^{11}$ Pross, C., Paying for the Past: The Struggle over Reparations for Surviving Victims of the Nazi Terror, translated by Belinda Cooper, John Hopkins University Press; 1998.

12 Pinel, A., and Kemuto Bosire, L. Traumatic fistula: the case for reparations. Forced Migration Review 2007 (27): 18-19. 